Особливої турботи й уваги потребують студенти під час складання сесії. Під час індивідуальних бесід із окремими студентами та академічною групою в цілому, слід запобігати виникненню кризових стресових станів. Щира турбота про студентів із боку куратора в період екзаменаційної сесії створює у них відчуття впевненості та підтримки, унаслідок чого зростає повага та довіра до наставника академічної групи. Дбайливе ставлення куратора породжує відчуття взаємопотреби, необхідності у спілкуванні, що, безумовно, впливає на загальну дружню атмосферу у групі, створює сприятливі умови для подальшої навчально-виховної роботи.

Водночас, слід зазначити, що в індивідуальній роботі куратор має бути тактовним, дотримуватися відчуття міри, оскільки надмірне піклування, постійне втручання в особистий простір студента можуть викликати негативну реакцію або сформувати у них негативні якості. Правильний індивідуальний підхід у роботі куратора свідчить про високий рівень педагогічної майстерності викладача, про його мистецтво тримати під постійним ненав'язливим контролем усю академічну групу, керувати іiі діяльністю, своєчасно впливати на кожного окремого студента, прагнути до створення гармонійно розвиненої особистості майбутнього педагога-професіонала.

\title{
Література
}

1. Буяльська T. Теоретичні та практичні аспекти роботи кураторів 3 адаптації студентів першого курсу в умовах вищого навчального закладу / Т. Буяльська, М. Прищак // Вісник Вінницького політехнічного інституту. - 2008. - № 5. - С. 105-112. 2. Гончаренко С. Український педагогічний словник / С. Гончаренко. - Київ : Либідь, 1997. - 365 с. 3. Гура С. Роль куратора в адаптації студентів інженерів-педагогів / С. Гура // Проблеми взаємодії мистецтва, педагогіки та теорії і практики освіти : [зб. наук. пр.]. - Харків : Харківський ін.-т мистецтв ім. Котляревського, 2000. - Вип. 5. - С. 180-185. 4. Кузлякіна В. Формування колективної свідомості студентів під керівництвом куратора групи / В. Кузлякіна // Сучасна молодь : крок у майбутнє : [матеріали I Міжнар. наук.-практ. конф. для студ.та аспір.].Суми : СумДПУ ім. А.С. Макаренка, 2006. - С. 210-213. 5. Марченко Г. Теоретичні засади виховної діяльності куратора студентської групи / Г. Марченко // Збірник наукових праць Військового інституту Київського національного університету ім. Т. Шевченка. - Київ : ВІКНУ, 2012. - С. 302-307. 6. Матвіїшин Л. П. Роль куратора групи в організації навчальновиховного процесу / Л. П. Матвіїшин. - Клінічна та експериментальна патологія : [щоквартальний український науково-практичний журнал]. - Чернівці, 2011. - Т. 10. - № 3 (37). - С. 34-37. 7. Ожегов С. И. Толковый словарь русского языка: 80000 слов и фразеологических выражений / С. И. Ожегов, Н. Ю. Шведов. - [4-е изд., доп.]. - Москва : ТЕМП, 2004.- 944 с. 8. Педагогічний словник/ [за ред. дійсного члена АПН України Ярмаченка М. Д]. - Київ : Педагогічна думка, 2001. - 516 с. 9. Романова С. В. Організаційно-виховна робота куратора академічної групи у вищих технічних навчальних закладах : дис. на здобуття наукового ступеня канд. пед. наук: 13.00.07 / Романова Світлана Вікторівна. - Слов'янськ, 2006. - 257 с.

УДК 371.2: 82.09 (477)

Інна Горячок

\section{ЛІТЕРАТУРНИЙ РОЗВИТОК СТУДЕНТІВ ЗАСОБАМИ КІНОМИСТЕЦТВА}

Горячок I. В. Літературний розвиток студентів засобами кіномистецтва.

У статті розглядаються особливості взаємодії української літератури та кіно.

Педагогіка вищої та середної школи. - 2015. - Вип. 45 
Визначено їх значущість та дієвість для духовного розвитку молодого покоління. Запропоновано низку інноваційних методів та прийомів для реалізації літературної освіти студентів засобами кіномистецтва.

Ключові слова: взаємодія мистецтв, література, літературний розвиток, кіномистецтво, фільм, інноваційні прийоми.

Горячок И. В. Литературное развитие студентов средствами киноискусства.

В статье рассматриваются особенности взаимодействия украинской литературы и кино. Определены их значимость и действенность для духовного развития молодого поколения. Предложен ряд инновационных методов и приемов для реализации литературного образования студентов средствами киноискусства.

Ключевые слова: взаимодействие искусств, литература, литературное развитие, киноискусство, фильм, инновационные приемы.

Goriachok I. V. Literary development of students by means of cinematographic art.

In the article deals with the peculiarities of interaction between Ukrainian literature and cinema. Their significance and effectiveness are defined for the intellectual development of young generation. A number of innovative methods and techniques are suggested for the implementation of literary education of students by means of cinematographic art.

Key words: interaction of arts, literature, literary development, cinematographic art, film, innovative techniques.

Література як навчальний предмет художньо-естетичного циклу має велике значення у становленні духовного світу особистості, формуванні естетичних почуттів, а також створює сприятливі умови для взаємодії мистецтв. Плідна та творча робота на заняттях літератури з поєднанням різних видів мистецтв $\epsilon$ важливою для розширення світогляду студентів, молодь бачить зв'язок літератури як предмета 3 різними сторонами життя, це допомагає усвідомити та зрозуміти саме визначення літератури як мистецтва слова. Це сприяє збагаченню людини як духовно, так й інтелектуально. Означена проблема недостатньо висвітлена в методичній літературі, чим і зумовлена актуальність нашого дослідження.

Однією 3 головних видових ознак кіномистецтва $є$ єдність просторово-часового відображення дійсності в тї русі, в усій багатоманітності відношень та зв'язків. Кінематограф як вид мистецтва відрізняється від інших своєю синтетичністю. У ньому синтезовані естетичні якості літератури, театру, образотворчого мистецтва, фотографії, музики, досягнень у галузі оптики, механіки, фізіології.

Кіно, на думку А. Гельмонда, - це більше, ніж звичайна розвага, ніж саме мистецтво. Це нова форма народження думки, нова форма ії вираження; це мова, якою повинні володіти ті, хто навчається, і ті, хто навчають [2, с. 35]. Відомий естет Р. Рабинович переконував: «Літературний образ на екрані стає конкретним, наочним, життєвим, реальним; і те, що в уяві могло бути невиразним, неясним, приймає чіткі окреслення, виявляється, як на плівці. Кіно дозволяє по-новому прочитати, побачити твір художньої літератури, відкриваючи в ньому не помічені раніше красу і глибину, надаючи тим самим матеріал для розвитку образного мислення» [4, с. 231].

Метою статmі: 3'ясувати особливості літературного розвитку студентів у процесі вивчення української літератури засобами кіномистецтва. 
У процесі вивчення української літератури традиційно використовуються різні види фільмів:

- ігрові (художні), які реалізують засобами виконавчої творчості задум кіно драматичного твору чи адаптованого твору поезії чи прози («Чорна рада» П. Куліша, «Лісова пісня» Лесі Українки, «Скляне щастя» Г. Тютюнника, «Вавилон ХХ» В. Земляка);

- мультиплікаційні («Пригоди козака Енея» за I. Котляревським, «Парасолька на полюванні» (за мотивами оповідань Остапа Вишні «Мисливські усмішки»), «Тополя»за Т. Шевченком);

- документальні, зокрема навчальні, в основу яких покладені зйомки реальних подій та осіб («Відкрий себе» про Г. Сковороду, «Сон» про Т. Шевченка, «В. Підмогильний розстріляне відродження», О. Гончар «Собор» та інші).

Екранізація літературної класики, що текстуально вивчається в університеті, - це новий твір мистецтва. У процесі «перекладу» з однієї знакової системи на іншу утворюються нова форма й зміст. Під час трансформації літературні образи змінюються кінематографічними. Кожен такий творчий акт - це віднайдення естетичного еквівалента в царині іншого виду мистецтва [3, с. 101].

Методика роботи на заняттах літератури із залученням кіно має свою специфіку. Кіномистецтво постає принципом створення загальної моделі художнього аналізу фільму й твору літератури. Для художнього аналізу кінострічки (як і будь-якого іншого твору мистецтва) потрібні знання основних художніх прийомів, структурних елементів, природи умовності цього виду мистецтва. Аналіз, який грунтувався на поетапно набутих теоретичних знаннях, розширював і поглиблював уміння бачити кінематографічний текст як мистецьке явище. Поступово, коли системно буде використовуватися залучення кіно до занять, студенти навчаться розглядати кожний складник, який у конгеніальному еквіваленті представляв собою начебто мікроструктуру загальної образно-емоційної картини буття, виявляючи художню закономірність цілого. Вони навчаться бачити художню логіку розвитку авторських думок, розпізнавати, як народжується кіномистецький образ, порівнювати й аналізувати.

Кіно у процесі вивчення літератури $є$ цінною образотворчістю тільки тоді, коли вона не порушує загальної системи вивчення предмета, а органічно поєднується 3 нею, посилюючи іï специфічними виразовими засобами.

Визначаємо дві моделі синтетичної взаємодії кіномистецтва у процесі:

- вивчення біографії письменника (на прикладі життєвого i творчого шляху О. Довженка, І. Драча, Ю. Андруховича);

- інтерпретації художнього тексту (В. Барка «Жовтий князь», О. Кобилянська «Земля», І. Франко «Борислав сміється»).

За допомогою введення кіномистецтва в навчальний процес літературна освіта студентів удосконалюється, а модель порівняльного розгляду за двома блоками літературним і кінематографічним - виявляється ефективною. Тому пропонуємо зразки міжмистецької взаємодії кіно та літератури на матеріалі відомих авторів XX ст.:

\begin{tabular}{|c|c|}
\hline \multicolumn{2}{|c|}{ Література ХХ ст. } \\
\hline М. Хвильовий & $\begin{array}{c}\text { Документальна кінострічка «Цар і раб хитрощів». Екранізації: } \\
\text { кінотрилогія «Танго смерті» (за мотивами «Повість про санаторійну } \\
\text { зону»), «Геть сором!» («Сентиментальна історія»), «Вальдшнепи». }\end{array}$ \\
\hline М. Драй-Хмара & Документальна стрічка «М. Драй-Хмара. Останні роки». \\
\hline
\end{tabular}




\begin{tabular}{|c|c|}
\hline \multicolumn{2}{|r|}{ Література ХХ ст. } \\
\hline О. Вишня & Біографічна картина «Із житія О. Вишні» (О. Довженко). \\
\hline В. Підмогильний & $\begin{array}{l}\text { Документальний } \\
\text { відродження». }\end{array}$ \\
\hline М. Куліш & $\begin{array}{c}\text { Екранізації: «Народний Малахій», «Мина Мазайло», «Закут». } \\
\text { Стрічки про автора «Пастка», «Тягар мовчання», «Микола Куліш». }\end{array}$ \\
\hline О. Довженко & $\begin{array}{l}\text { Власні екранізації: «Земля», «Зачарована Десна», «Незабутнє» } \\
\text { («Україна в огні»). }\end{array}$ \\
\hline О. Гончар & Документальний фільм «Собор». \\
\hline М. Стельмах & Екранізації: «Гуси-лебеді летять», «Щедрий вечір». \\
\hline В. Барка & Екранізація: «Голод-33» («Жовтий князь»). \\
\hline В. Земляк & Екранізація: «Вавилон XX» («Лебедина зграя»). \\
\hline В. Шевчук & Екранізація: «Голос трави» («Дім на горі»). \\
\hline Григорій Тютюнник & Екранізація: «Вир». \\
\hline Григір Тютюнник & $\begin{array}{c}\text { За мотивами творів «Скляне щастя» («Син приїхав»), «Климко» } \\
\text { («Дід Северин», «Вогник в степу»), «Три плачі над Степаном». }\end{array}$ \\
\hline Шістдесятники & $\begin{array}{c}\text { Актори: І І. Миколайчук, Б. Ступка, А. Кадирова; режисери: } \\
\text { Л. Танюк, С. Параджанов, К. Муратова, Л. Осика, М. Ільєнко. }\end{array}$ \\
\hline А. Малишко & $\begin{array}{l}\text { Автор сценарії кінокартин: «Навіки } 3 \text { російським народом», } \\
\text { «Квітуча Україна», «Ми } 3 \text { України». Написав тексти пісень до } \\
\text { фільмів: «Макар Нечай», «Богдан Хмельницький», «Чорноморочка» } \\
\text { та ін. Йому присвячено науково-популярну стрічку «Андрій } \\
\text { Малишко». }\end{array}$ \\
\hline
\end{tabular}

У взаємодії кіномистецтва 3 літературою ми зупинились на таких інноваційних прийомах роботи зі студентами:

«Вільне письмо». Пропонований вид роботи допомагає сконцентрувати власні думки через їх записування без зупинки. Для роботи надається певний час (5-10 хв). Протягом цього часу студенти записують свої думки стосовно запропонованої теми, не припиняючи роботи. До уваги не беруться стиль та орфографічні чи пунктуаційні помилки.

Суть роботи полягає в тому, що з'являється можливість зафіксувати свої емоції, не соромлячись їх. «Вільне письмо» («Письмо для себе», «Есе») варто використовувати на етапі усвідомлення матеріалу. Наприклад, після перегляду кінострічки буде доречно, щоб студенти висловили свої думки після побаченого, пережитого, порівняли та проаналізували мистецтво слова та мистецтво гри, дії тощо.

«Ланцюжок» - способи задіяння до роботи максимальної кількості студентів:

- ставлять запитання одне одному по черзі;

- той, хто відповідає, ставить запитання наступному (того, хто відповідатиме, визначає сам або це робить викладач);

- обраного студента викликають до дошки, і всі охочі ставлять йому запитання за темою.

Лист до кіногероя або автора (робота в парах). Листи призначені для стимулювання діалогу між двома глядачами у формі запитань та відповідей.

Bapiaнm № 1. На основі опрацьованого матеріалу студент обирає «предмет», щодо якого триватиме діалог. Під час виникнення в нього думок і міркувань він записує їх на аркуші й пропонує сусідові для обміну інформацією чи отримання відповіді. Адресат відповідає, записуючи свої думки чи запитання, адресовані сусідові. Орфографічні, пунктуаційні та граматичні помилки в цьому випадку не враховуються. Запитання, на які в 
пари відповіді не знайшлося, наприкінці вправи озвучуються, відповідь формулюють усі студенти в групі (чи за допомогою викладача).

Bapiaнm № 2. Спочатку кожен із пари записує два-три запитання, які йому хотілося б поставити авторові твору. Потім підготовлені запитання кожен пропонує сусідові, який, у свою чергу, намагається сформулювати на нього відповідь, суть якої коротко також записується (оскільки ці записи - це своєрідний процес мислення й не призначені для широкого загалу, на орфографічні, граматичні та синтаксичні помилки не зважають). Після завершення роботи в парах запитання, на які не було знайдено відповіді, озвучують, і всі намагаються відповісти на них.

Обміркуйте/об'єднайтеся в пари/обміняйтеся думками. Запропонуйте завдання або питання для обговорення. Після пояснення питання або завдання дайте студентам 1-2 хвилини для продумування можливих відповідей або рішень індивідуально. Об'єднайте учнів у пари, визначте, хто з них буде висловлюватися першим, і попросіть обговорити свої ідеї одне з одним. Краще відразу визначити час на висловлення кожного в парі і спільне обговорення. Це допомагає звикнути до чіткої організації роботи в парах. Вони мають досягти згоди (консенсусу) щодо відповіді або рішення. (Наприклад, резюмувати побачений фільм, проаналізувати зображення того чи іншого актора із літературним персонажем тощо).

Почережні запитання. Заздалегідь визначте, які одиниці фільму будуть обговорюватися. Після перегляду кінофрагменту студенти працюють у парах і ставлять по черзі одне одному запитання. Приклади: Запитайте про основні ідеї («Що є найважливішим 3 того, що хотів показати режисер/автор»). Намагайтеся прояснити деталі («Що, на твою думку, автор має на увазі під ...? Який стосунок має ця ідея до головної теми?»). тематично поєднайте те, що було сказано, з тим, про що йтиметься в тексті («Що нам тепер необхідно дізнатись? Як Ви вважаєте, про що далі говоритиме автор тексту?»).

Відеофрагменти як візитна картка художнього твору. Відеофрагменти - це відзняті на відеоплівку 7-12 хвилинні екранізації художніх творів [4]. Загалом відеофрагмент- це екранізація не всього художнього твору, а лише згустку найдраматичніших подій; подій, які $\epsilon$ найважливішими для розвитку сюжету, для характеристики головних героїв, визначення стилю письменника, зокрема, мови твору.

Відеофрагменти зручні, прості для використання абсолютно всіма викладачами й доцільні на заняттях, де вивчаються прозові та драматичні твори.

Відеофрагменти можуть бути використані на заняттях словесності різних типів: лекційне, семінарське, практичне.

За допомогою відеофрагментів можна пожвавити будь-який етап заняття - його організаційну частину, мотивацію навчальної діяльності, перевірку і корекцію знань студентів, вивчення нового матеріалу, його закріплення, домашнє завдання.

Основне завдання відеофрагментів як засобу навчання - сприяти якісному виконанню програми з української літератури з мінімальною затратою часу на підготовку до заняття та реалізацію його мети.

Отже, література завжди була чи не основним джерелом, із якого режисери черпали ідеї для своїх фільмів. Натомість кінематограф дарує літературним творам друге життя після екранізації того чи того твору. За допомогою правильних методів роботи зі студентами твори набувають нового забарвлення, розуміння та засвоєння.

\section{Література}

1. Бабійчук Т. В. Методика створення i використання відеофрагментів художніх творів у процесі вивчення української літератури в педагогічному коледжі : авторереф. дис. 
на здобуття науковго ступеня канд. пед. наук : спец. 13.00.02 «Теорія і методика навчання (українська література)» [Електронний ресурс] / Бабійчук Тамара Василівна. - Київ, 2007. Режим доступу : http://librar.org.ua/sections_load.php?s= philology\&id=1759\&start=6 2. Гельмонт А. Кино на уроке: Кино как наглядное пособие и общая методика его применения / А. Гельмонт. - Москва : Изд-во АПН РСФСР, 1961. - 102 с. 3. Прессман Л. Дидактические основы применения экранно-звуковых средств в школе/ Л. Прессман.Москва : Педагогика, 1987. - 152 с. 4. Рабинович Р. Фильмы-экранизации на уроках литературы и воспитание художественного вкуса у старшеклассников / Р. Рабинович// Искусство в школе. - Москва : Просвещение, 1964. - С. 224-250.

УДК 378.147

Іван Касілов

\section{РОЗВИТОК ВИКОНАВСЬКОЇ ТЕХНІКИ СТУДЕНТІВ-ГІТАРИСТІВ У ПРОЦЕСІ НАВЧАННЯ НА ФАКУЛЬТЕТІ МИСТЕЦТВ}

Касілов І. А. Розвиток виконавської техніки студентів-гітаристів у процесі навчання на факультеті мистецтв.

У статті висвітлено основні проблеми становлення та розвитку виконавської техніки, а також загального професійного рівня майстерності гри на шестиструнній класичній гітарі в умовах освітньої програми України. Розкрито історичні особливості виникнення інструменту та розглянуто методичні шляхи розв'язання основних виконавських задач.

Ключові слова: прийоми звуковидобування, специфіка звукоутворення, ігровий апарат, приготовлені та робочі рухи.

Касилов И. А. Развитие исполнительской техники студентов-гитаристов в процессе обучения на факультете искусств.

В статье освещены основные проблемы становления и развития исполнительской техники, а также общего профессионального уровня мастерства игры на шестиструнной гитаре в условиях образовательной программы в Украине. Раскрыты исторические особенности возникновения инструмента и рассмотрены методические пути разрешения основных исполнительских задач.

Ключевые слова: приёмы звукоизвлечения, специфика звукообразования, игровой аппарат, приготовленные и рабочие движения.

Kasilov I. A. The development of students' performance abilities in learning guitar at the faculty of Arts.

The article deals with the main problems of formation and development of performance technique as well as the common professional level in playing six-string classical guitar in the context of educational program in Ukraine. The historical features of musical instrument appearance are given as well as the methodical ways for the solution of the main performing problems are considered.

Key words: methods of phonation, sound creation specific features, musical instrument, movements of preparing and working basis.

У контексті сучасної освітньої програми стає актуальною проблема фахової підготовки студентів в умовах педагогічних навчальних закладів. Зростання сучасних вимог 